\title{
Death as Volition: Suicide in the Early Azorín
}

La muerte en Azorín es una constante desde sus primeros relatos de fines del siglo XIX hasta sus obras más maduras de la década de los cuarenta. Este artículo analiza el suicidio en Buscapiés (I894), Bohemia (I897) y Diario de un enfermo (I90I). Con la publicación de La voluntad en 1902, los personajes desmuestran una voluntad insuficiente para suicidarse. En cambio, los personajes en obras anteriores manifiestan su determinación para escapar de situaciones insoportables por medio del suicidio. Demuestro que el suicidio es consecuencia de una decisión desesperada y de un conflicto entre palabras, escritura y existencia al que se enfrentan los protagonistasescritores de Bohemia y Diario de un enfermo. En el caso del político de Buscapiés consituye asimismo una clara condena del gobierno español de la Restauración.

Palabras claves: Azorín (I873-1967), Buscapiés, Bohemia, Diario de un enfermo, muerte, suicidio, reflexividad, decadencia

Death looms over Azorín's works from his earliest short stories to his more developed novels of the 1940s. This article examines three instances of suicide in Buscapiés (I894), Bohemia (I897) and Diario de un enfermo (I90I). With the publication of La voluntad in 1902, Azorín's characters show a lack of will to take their own lives. In previous works, however, characters manifest sufficient determination to escape unbearable tensions through suicide. I argue that suicide in his early works results from a desperate resolve and the conflict between words, writing and existence that confront the two writerprotagonists in Bohemia and Diario de un enfermo. In the case of the civil servant in Buscapiés it becomes an overt condemnation of Spain's Restoration government.

Keywords: Azorín (I873-1967), Buscapiés, Bohemia, Diario de un enfermo, death, suicide, reflexivity, decadence

In Azorín's early fictions published in the 1890 os three characters commit suicide: a civil servant, a young aspiring writer, and a diarist. Leaving aside for the moment the death of the civil servant, whose suicide serves as an 
overt condemnation of Spain's Restoration government, a symbol of the social and political opposition expressed by Azorín and other young writers of his literary stable in the I89os, I begin with an analysis of the suicides of the writer and the diarist in Bohemia and Diario de un enfermo, respectively. These tortured writers illustrate paradoxically how suicidal thoughts and illness inspire artistic creativity. Words fail these protagonists as they attempt to write, but what is unexpectedly produced are strong esthetic descriptions in spite of the writer's mental instability and illness. These characters seek to reconcile a secure existence as writers against their philosophical challenges about writing. For them, writing is a constant struggle for expression and representation that points to language's limitations which undermine the productivity of each author. But to cease to write means to give up one's vocation and reflection on language in exchange for happiness and mental stability. The result of these paradoxes is these writers' books to be read and admired by others.

Death is ubiquitous in Azorín. It appears in his earliest texts and persists into his more mature novels, from Bohemia published in I894 to $E l$ enfermo of i943. This somber theme also manifests itself in Azorín's works of the r1920s Una hora de España (1924) and Doña Inés (1925). However, in Azorín's future works, suicide becomes an impossible act because it requires determination beyond the capability of Azorín's characters. This paper examines the process of suicide in the early Azorín in light of the predominance of death in Azorín's later works. We normally expect only Azorín's novelistic characters to be inactive and lack willpower, to support Santiago Riopérez's valid claim that "there is no manifest or valiant death in the pages of Azorín" (I26). The difference between the novels La voluntad, Antonio Azorín and his previous shorter works such as Bohemia and Diario de un enfermo with respect to death is the change in focus from suicide to other forms of ending one's life. Azorín's earlier characters, as will be analyzed here, endure social hardships similar to those of the character Antonio Azorín in La voluntad, and are equally preoccupied with mortality, but they overcome their negative circumstances through

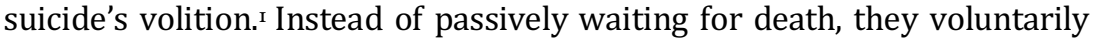
take their own lives to escape their hardships.

Informed by his readings of Hyppolite Taine, Auguste Comte, and JeanMarie Guyau, available in Spain in the I89os, Azorín's realist settings for his short fictions and novels imprison his subjects' personalities. ${ }^{2}$ In Buscapiés, the representations of urban environments are described in dreary colors: ashen clouds cover the skies looming over Madrid; everything in the city is monotonous; and the characters suffer from a general malaise toward life. Azorín's descriptions of rural spaces are similar. These also evoke a lack of 
light and optimism in the face of a constant awareness of death: "y la muerte está continuamente ante la vista de estos seres ... En todos los pueblos, en todos estos pueblos españoles, tan opacos, tan sedentarios, tan melancólicos, ocurre lo mismo" (565). Antonio Azorín, La voluntad's protagonist, believes that he would have become a different person had he lived elsewhere. Apparently, residence in Yecla, Monóvar and Madrid has led to an evaporation of his will: "Las cosas nos llevan de un lado para otro, fatalmente; somos de manera que el medio conforma nuestro carácter" (Martínez Ruiz, Obras completas 512).

Along with the effect of the environment on the characters, Azorín also incorporates a dolorido sentir de la vida, an overwhelming awareness of anguish in life that transcends the circumstances of one's place and time as expressed by the leit-motif of the man with the hand on his cheek in Martínez Ruiz's "Una ciudad y un balcón." This scene is repeated three times at the end of each section of this piece: "El caballero se halla sentado en un sillón; tiene el codo puesto en uno de los brazos del asiento y su cabeza reposa en la palma de la mano. Los ojos del caballero están velados por una profunda, indefinible tristeza..." (Castilla 690). Yuste, Azorín's mentor in La voluntad, observes: "y sentirse vivir es sentir la muerte, es sentir la inexorable marcha de todo nuestro ser y de las cosas que nos rodean hacia el oceáno misterioso de la nada" (Martínez Ruiz, Obras completas 1975 492). This ever-present awareness of death in life also conditions how his characters view everything around them. From this perspective, life becomes a slow and steady march toward death, and death gives purpose to life: "Las causas iniciales de la vida y de la muerte son las mismas: una implica la otra," wrote Martínez Ruiz in Historia y vida (22).

With respect to death, Azorín's characters exist between the past and the future: death has yet to arrive - todavía no - and yet it has been - ha sido. Their bodies are a combination of what still remains and traces of what has been, as Antonio Azorín's narrator observes: "Ya don Víctor no es casi nada; es un resto de personalidad; es un regazo lejano de ente humano" (Martínez Ruiz, Obras completas 1975 585). These suicides in Azorín's early works forestall this aging process, a gradual decline toward death where our bodies still may show some traces of youth - of what has been - and signs of old age and ultimately death, or what has yet to arrive. These early characters stand as a variation on the theme of death and are significant instances of volition that contrast with a lack of will in future works. Furthermore, these suicidal characters initiate a reflection on language, literature and the writer that will appear again in later novels. 
In Azorín's novelistic worlds, a dominant environmental determinism, tempered by an always present consciousness of death, helps reveal the personalities of his characters. The suicidal protagonist in "Una vida," a short dramatic dialogue organized in four acts and compiled as Bohemia, feels misunderstood by his brother, sister, and parents. At first glance, we might interpret his suicide as a result of his contentious social environment or perhaps his paralytic condition. At twenty-five years old, the character-writer is restricted to a wheelchair, a physical limitation that parallels his intellectual writer's block. His unkempt appearance, complete with pale complexion, and long, untrimmed beard - which he presumably refuses to shave, perhaps because it makes him seem introspective imitates that of an absent-minded philosopher deep in thought. Furthermore, his iconoclastic ideas embarrass his family's middle-class sensibilities: he has refused to become a doctor or lawyer, instead wasting family money on bohemian nonconformity and misadventures, which have resulted in his dependent condition, as is clarified by his mother's biting comments: "Bien; no hablemos de ello si te has de poner así. Después de todo... tú eres el causante de lo que ocurre" (Martínez Ruiz, Obras completas 175$)$. He is in a perpetual argument with his family from whom he receives financial support but who, at the same time, rejects him for his own physical problems. While he attempts to defend his writing pursuits, his family now must care for his basic necessities: "No quiero vivir aquí; no quiero pasar mi vida en perpetuo martirio..." (I75). The subtle abuse the young man tolerates from his family's words and gestures makes him miserable; the protagonist would like to forget his past but his family constantly reminds him of it. This treatment is also a result of his vocation as a struggling writer. While frustrated with the slow pace of his work, he is also unable to sustain his thinking in such a hostile environment.

Although the protagonist remains in a state of paralysis leading to his ultimate demise, the writing desk in the living room is covered with books and papers, signs of a still active curiosity, and an indication that he continues to read and write amidst the negativity of his family. The ideas in his books and newspapers validate his choice to keep himself intellectually engaged despite his family's criticisms. His sister reminds him of the advice his parents used to give him but that he did not follow: "Que tus ideas eran descabelladas ... que no podían conducir sino a la cárcel y a la deshonra... al escándalo ... Y no nos hiciste caso... Te empeñaste en seguir esas locuras ... olvidando tus estudios... gastando el caudal de la familia ..." (176). Following his sister's chastisement, the protagonist compares himself to don Quijote who also sought justice while out of mind and place "La eterna cuestión ... Sí; podía haber sido un buen burgués, cerrado a toda 
iniciativa generosa, a todo ideal grande, y ... sólo soy ... un amigo de la verdad, un enamorado de la justicia... un quijote!" ( 176 ). The characterauthor realizes that he could have lived a middle class life but only at the expense of his ideals. In Act IV, exhausted by the need to defend himself, he decides to take his own life. He sits quietly near a window, his head resting in the palms of his hands, immobile. Suddenly, inspired by an idea, he returns to his writing table, but as soon as he has scribbled a few lines, his disposition changes, and he rips up the paper. He raises himself painfully from the chair, and moves closer to the balcony, in a tremendous effort to reach the door leading to the ledge outside. As he approaches the door, his mother, brother and sister, who now appear just inside the room, stop to observe silently and attentively the actions of the character-writer. With a final burst of strength, the young man pulls himself up over the railing of the balcony and falls to his death, and the family members quietly disappear from the scene ( 176$)$.

The young man's suicide seems to have been motivated by two factors based on the details in the story. On the one hand, we can understand his suicide from a sociological perspective with respect to the family. First introduced by Emile Durkheim in 1897 in his groundbreaking work Suicide, A Study in Sociology, his explanation for suicide accords with Azorín's deterministic viewpoint which conditions his characters' personalities. Durkheim conceived of four types of suicide based on degrees of imbalance between the endpoints of social integration and moral regulation. He argued that people tended to commit suicide at both sides of the scale: if they were too socially integrated or if they did not regulate themselves morally. Egotistical suicide, for example, occurred when a person, like the writer-protagonist in "Una vida," experiences minimal social integration. Unmoored to a spouse or family who can lend them encouragement and guidance, these subjects receive little moral direction from their social group. Durkheim found that unmarried people had higher rates of suicide because they had less social reinforcement that would bind them to social norms. In this example, unmarried people experienced too little social integration and social regulation. In Azorín's story, the young man is unmarried and confined to a wheelchair. Under these circumstances we can see how difficult it would be to establish social bonds. Furthermore, his family, the only social group with which he has daily contact, does not support his goals. Instead, they constantly remind him of his sordid past which has somehow resulted in his paralytic condition. As such, suicide becomes an escape from an environment in which he feels alienated as both a writer and son. Through suicide the character abandons his circumstances to not only alleviate his pain but 
also to seek revenge upon his family who feel the guilt and hopelessness in the aftermath of the young man's death.

Durkheim's explanation for suicide, based on sociological factors, leaves aside psychological or work-related explanations. The fact that the young man is also a writer invites another possible explanation for suicide connected to his vocation. The character feels withdrawn from his family but also from the source of his craft - words themselves. French novelist and literary critic Maurice Blanchot developed a theory particularly suited to the concerns of Modernist literature which informed his provocative essays. In "Literature and the Right to Death," Blanchot argues that negation and language work together in that "language perceives that its meaning derives not from what exists but from its own retreat from existence" (324). Following Hegel's method of negation to prove what is actually real, Blanchot claims that to know anything we must first annihilate it, a bold claim which implies that words and language as a system of representation must be interrogated and stripped away for us to return to a state of existence without words. Prior to language, there is only unnamed existence. Once we are able to use language as our brains develop we begin to name things. Previously unrepresented material become ideas, concepts or, in the most literaral sense, the thing itself. What once existed without a name or word attached to it is now replaced by what it is not: "The word gives me being, but it gives it to me deprived of being. The word is the absence of that being, its nothingness, what is left of it when it has lost being - the very fact that it does not exist" (Blanchot 322). Language strips material existence of its being and replaces it with abstractions or categories in our minds. In this understanding of language, writers hold a special place because of their relationship to words. Writers destroy being through their special use of words. As Blanchot explains, "Clearly in me the power to speak is also linked to my absence of being" (324). Using Blanchot's logic, the writer is the person most alienated from existence and, as creator of imaginative literature, constructs fictions that amount to a cemetery, a place where what was once alive - existence and being - is now replaced and represented in words - the death of existence. Language and a writer's life are bound together through their existential absences and contradictions, and the writer feels these tensions most acutely: for a writer to return a word to its essence would require either silence or suicide, a preverbal state in a world without words or life. A writer must either relinquish the profession he seeks and thus kill the vocation while saving his life, or take his life and the writer with it. Blanchot concludes "Literature and the Right to Death" by identifying a double meaning in language and thus in life, literature and the writer. The 
reality of language is to "obscure the depths of existence" in order to become an idea: "It is that life which supports death and maintains itself in it - death, the amazing power of the negative, or freedom, through whose work existence is detached from itself and made significant" (343). Language signifies and represents but in an indirect and paradoxical fashion. Language can give meaning to both life and death but it also, for Blanchot, creates a barrier between what is real and what is represented on behalf of the real.

We may be surprised that a writer would be so horrified over the representational aspect of language to the point of suicide, illness or silence. It makes sense to point out that a writer would internalize something so basic to language, that is, language's role as representation to communicate with the reader. Yet, these character-writers are highly selfreflexive and constantly ponder and challenge the limitations of language to represent what they observe and feel. In his entry for February 25, I899 the diarist describes his return to writing through illness. A lack of health that threatens his existence but leads him to write: "Me devora la fiebre. Ayer estuve escribiendo toda la tarde, toda la noche, rápidamente, frenéticamente" (Martínez Ruiz, Obras completas 383). But this burst of productivity creates a new dilemma that is not easily reconciled for the diarist. In his feverish pace, he painfully recognizes the infinite nature of his imagination to produce literature but also the impossibility to name what he imagines: “¿Días crueles! ¿Hay dolor como éste? ¿Hay dolor como pensar a todas horas, a pesar de todo, contra todo, en el asunto indefinido del libro comenzado?" (383). Overwhelmed by his impending project that seems to open up infinite possibilites, the writer is faced with an abundance of images - his imagination is alive - yet he cannot summon forth the words to designate them: "Ya es la frase exacta que no encuentro, la remembranza de una actitud que quiero clavar en las cuartillas, la visión de un paisaje que quiero hacer visible y plástico..." (383). Again, he reaches another realization and dilemma: language is limited in its power to represent. While the imagination is unrestricted, writers may not always be able to convey their conceived images in words. Exhausted by his attempts to put words to what he can only imagine, the diarist stops writing: "Caigo en un largo y profundo sopor; ni una línea puede escribir mi pluma desmañada y torpe" (383). He is discouraged by the limitations of words, but they must sustain his work: "... las sensaciones han venido a ser múltiples y refinadas, la palabra, rezagada en su perfectibilidad, se encuentra impotente para corresponder a su misión de patentizar y traducir lo que siente" (385). In this case the diarist shifts from a word representing what he observes, i.e. reality, to what he feels about that same 
reality, intensifying the writer's despair at the impotence of language. A personal, sensual and emotive response to the world is even more difficult to capture in words. Language now has a dual role within the diary - one of describing the Spanish landscape and the other of expressing the emotion roused by that same landscape.

Blanchot's paradoxes come into fuller view as we continue to consider Diario de un enfermo, an early novel-like text that serves as prelude to $L a$ voluntad. Illness, death and suicide loom over this text. From the diarist's first journal entry, he comments on the astonishing sadness of living, stating that he lacks plans or sense of direction. The diarist feels disoriented and senses his future as a writer diminish each day like a slow death. His loss of direction and impending doom seems strange for a young man of twenty years old, but may not seem out of place for a frustrated writer or diarist who feels the tension of language. Despite his bursts of productivity and vivid imagination, he questions why he has not achieved the fame he desires, comparing himself to the Romantic essayist Mariano José de Larra infamous for his suicide in his late twenties: " $\mathrm{i}$ Ah mis veinte años! ¿Dónde está la ansiada y soñada gloria? Larra se suicidó a los veintisiete años; su obra estaba hecha..." (Martínez Ruiz, Obras completas 379). However, while both the diarist from Diario de un enfermo and Larra commit suicide, the Romantic author established a literary reputation by the time of his suicide. Comparing himself to Larra, the young protagonist feels as if suicide at this point in his career would deprive him of a more successful writing career.

Interestingly, the diarist's suicide is not explicit when Diario de un enfermo was republished as part of Martínez Ruiz's complete works in 1947. The last line of the original text of r9or was deleted, but it was republished as a footnote in the 1975 edition of the complete works: "A la luz indecisa del crepúsculo, refleja, nikelado [sic.], sobre la mesa. Me levanto; lo cojo. - He sonreído" (4OI). Francisco J. Martín corroborates the use of the word "nikelado" as a reference to a revolver in an article that Martínez Ruiz published in El país on January I2, I897 (250-25I). In this article, the character pretends to take his own life with a revolver described as "niquelado." Other moments in Diario de un enfermo indicate that the protagonist will commit suicide: he inhabits the same room where his wife died just days before; an infinite sadness fills his soul; he cries to the point of suffocation; he rests on his wife's bed and lies down on the same pillow on which she died; the bedroom lamp slowly dims symbolizing the eventual end of his life: "Estoy cansado, fatigado. Siento una laxitud profunda en todo mi espíritu. No odio nadie. No tengo ansias de nada. Sobre la alfombra, yacen intonsos los libros que me mandan, los 
periódicos, las revistas. No tengo curiosidad de nada. Apenas pienso; apenas si tengo fuerzas para escribir estas líneas ... ¡Ah el tormento de vivir! ¡Ah la opaca vida, silenciosa, indiferente, muerta!" (400). Furthermore, the tone of the work strongly suggests death and the diarist's eventual suicide. His motivation is also evident and even conventional: he ends his life because he is overcome with grief over the loss of his wife. We assume that the diarist has yet to become a famous writer, which would have given his suicide a different motivation, perhaps eliminating the oblivion of death once he had gained fame through publishing. Larra also presumably committed suicide because of a lost love, the end of one of his many affairs. Montserrat Escartín Gual observes that the diarist ends his journal as he begins it by evoking the death of Larra who also committed suicide with a revolver (304).

Across all his entries the diarist is tormented by reading, note-taking and writing, skills and practices required to produce a book. This process alienates him from a life outside of writing as it pushes the diarist into a deeper state of social detachment and heightens his awareness of death. He remarks in his entry for December IO, I898 that he has worked numerous hours on his historical investigations. During these long hours he has taken copious notes, compiled quotations and handled many archival materials. He then asks himself if this activity is pointless, but more significantly, inhuman: “ ¿No es esto tonto? ¿No es estúpido, brutalmente estúpido, inhumano, brutalmente inhumano?" (Martínez Ruiz, Obras completas 380). The diarist perceives language - all those words he has read and written during his study session - as destroying social existence in exchange for knowledge only represented in his mind, echoing Blanchot's observations regarding language and existence. He yearns for something else: "Quiero vivir la vida en la vida misma; quiero luchar, amar, crear" (Martínez Ruiz, Obras completas 380). At this point the diarist makes a stunning realization: he becomes aware that there is a radical difference between who he is as a person and what he thinks. While the writer wishes to return to a form of being where words do not separate him from life itself, he realizes that, if he were to do so, he would have to pursue a life of non-writing. He cannot have it both ways, which illustrates the dilemma that Blanchot identifies as tormenting writers. To maintain his sanity, an author must abandon his craft or, if he chooses to continue, alienate himself further through literary creation that negates life. On December I2, I898, the diarist rejects books to consider a life of action: "No más libros; no más hojas impresas, muertas hojas, desoladoras hojas. Seamos libres, espontáneos, sinceros. Vivamos" (Martínez Ruiz, Obras completas 38I). For the diarist, a life without books, reading, writing and studying is equivalent 
to a life of spontaneity, freedom and sincerity; a creative literary life is equivalent to death, imprisonment and emotional inauthenticity. To be a writer is to choose isolation for the pursuit of knowledge and literature. To choose life, on the other hand, is to deny one's profession or the death of the writer in life.

Nature inspires the diarist to write but the city, on the other hand, evaporates his will to do anything. On May 8, I899 while still living in Madrid, he complains that he can no longer write because he finds himself disillusioned with modernization. He worries about car and train accidents, the greed and exploitation that has fueled modern industrialization, and the speed of urban life that is too fast to understand, let alone depict in words. By July 20 , now back again on the east coast of Spain, he is able to evoke this vibrant description of the natural landscape: "Y por todas partes, el empinado muro de las montañas grises, verdinegras, zarcas las lejanas; en una ladera, un pueblecillo microscópico, $\mathrm{y}$, a lo lejos, perdido en el horizonte, asomando por una garganta de piedra, el triángulo rojizo de un castillo moruno que luce a los postreros rayos del sol como un grano de oro..." (Martínez Ruiz, Obras completas 386). The diarist's description is invigorated by a subjective perspective. While the urban environment of Madrid was unnerving, the rural setting is more conducive to creativity. What is paradoxically produced reflects a desire for silence that dominates his writing in part two of the diary after he returns to Madrid. In the city, he seeks quiet places like churches and cemeteries that inspire silence through prayer and evoke death: "Por las dos bajas rejas se divisa el anchuroso coro. Arrodilladas, blancas en sus hábitos, tocadas de negro, las monjas rezan. Silencio, dulce reposo" (39i). The previous day, on November 19, 1899, the diarist records his observation of a funeral procession. He feels the irrepressible need to follow it, attracted by the powerful mystery of death. After the procession has arrived at the church, and the funeral is about to end, the diarist rambles anxiously through the silent, uninhabited part of the city. Silence is reiterated in the entry on February to where he suggests that silence, that is, words unspoken, conveys meaning more powerfully than words.

These passages, inspired by Larra's "Día de difuntos der836," also bring us back to Blanchot and his paradoxes of language (427-434). Blanchot says that language is "to communicate silence by words and express liberty by rules" (qtd. in Oxenhandler 37). As with other Blanchot maxims, the truth of language is discovered through paradoxes. Words unspoken can signify just as written words can evoke silence. In the diary, the color white signifies the absence of words on a blank page, silence and nothingness. For November 2I, I899, the diarist describes the whiteness he 
witnesses all around him from his position on the outskirts of Madrid: the white walls, the white clothing drying on the clothesline, and the blinding white sky. The use of "blancuzca" to describe the skyline maximizes the quality of whiteness to glaring proportions. It obliterates all other colors, like the striking light of the sun that makes it impossible to see anything, a kind of silence in light: "Brilla el sol; se oye el ronco rumor del Tajo y el persistente campaneo de las iglesias" (Martínez Ruiz, Obras completas 392). The silence is pierced by the distant rolling of the river and chiming of church bells: sounds not language. Signifying life or death - a new day or a funeral procession - the ambiguous descriptions of church bells permeate this portion of the diary. In the city, the bells express a tragic lament: "La campana de la catedral suena solemne, angustiosa ... El silencio pesa sobre nosotros" (393). Sounds and silence contrast to produce a paradoxical representation of the city. Sounds evoke stillness and death while the images of white walls, clothing and sky represent absence.

Absence is communicated not only through silence but also through the movements of the diarist's lover as she takes off her gloves: "Mientras ella se quita discretamente el guante, y al despedirnos, en silencio, yo siento inerte entre mis dedos su mano, larga, fina, sedosa" (395). He feels the absent hand of the lover he will eventually marry, an action recorded in the diary on January 20 , 1900 . Now married, the writer must integrate his professional life into this new relationship. By this point in the diary, he has come to a refined practice of his art by secluding himself so he can feel her presence through her absence: "Yo no quiero que ella me vea escribir. Escribir es utilizar la idea: el utilitarismo es la antítesis del arte. Quiero sentir hondamente la belleza a mis solas: no quiero profanarla, trasladándola a las cuartillas para que sepa el mundo que yo la siento" (397). The diarist does not wish to merely observe or translate reality onto the pages of his writing notebook. He wishes to convey a feeling that is born in the absence of his subject. Her imminent death, however, is a permanent absence the writer cannot overcome, and his worsening depression leads him to take his own life. What is left is a record of his struggles with language - the first part of the diary - and a record of silence - the second part - that mirrors the diarist's death at the conclusion of the work. This use of language to evoke silence demonstrates the suggestive power of words, one seductive enough to replace silence itself. Suicide then is his last act as writer and lover, and thus a conquest over the meaninglessness of his life by ending it. Finally, he cannot write himself out of his depression, and so his suicide comes to illustrate the linguistic suicide of the writer's words themselves in the death of the diarist. 
The texts themselves are the only basis that I have employed to explain suicide thus far. I have yet to look outside the text for other explanations, because recent biographical criticism may help explain suicide and death in Azorín's early works. Montserrat Escartín Gaul writes that Azorín's own moments of perceived illness (he may have been a hypochondriac) also contribute to the creation of his characters (134-35; 137-38). She argues that sick characters allow Azorín to analyze and cope with his own illnesses. Writing becomes both a form of self understanding and a mechanism to combat pain. Other critics have pointed out the high frequency of doctors in Azorín's novels (Granjel 316-335; Marco Merenciano II-23). Writing about characters who are ill and doctors who diagnose them is Martínez Ruiz's way of finding short-term solutions to his perceived illnesses. Understood in this way, writing can be seen as a cure.

In Bohemia and Diario, suicide is also the result of the paradoxes of language these characters illustrate. Turning now to the third instance of suicide we can now see it as a form of political criticism. ${ }^{3} \mathrm{~A}$ mood of general fatigue and nervous exhaustion permeates the stories included in Buscapiés, a collection of satirical pieces that includes short stories, literary and political criticism. Both its narrators and characters express negative attitudes toward the city, state, church and even the literary establishment. These fundamental institutions of modern Spain, particularly in Madrid, although not named in these stories, contribute to each character's illnesses and, in the most extreme case, his suicide.

The short story "Estaba escrito" concludes with an announcement from the morning newspaper La información: "Ayer tarde se suicidió disparándose dos tiros de revólver el conocido político de esta capital D. L. M. M., que desde algún tiempo a esta parte venía padeciendo una pertinaz dolencia" (Martínez Ruiz, Obras completas 49). The victim, Luis María Munárriz, however, discovers his own obituary while still alive at the beginning of the story. The obituary occupies the first seven paragraphs of the story and naturally describes Munárriz's career achievements. This opening scene is also the first instance in which we encounter a character reading about himself within a story, the initial example of the reflexivity trope in Azorín that will continue to define his work. The obituary describes the character as a dedicated and honest civil servant who held various important government positions. Because of the consequences of a long-term illness, it says, he was forced to retire from later political positions - Governor of Orense and Secretary of Civil Administration after which he dedicated himself to history producing a volume on Hispanic-Roman law. The obituary concludes by mourning the loss of a political champion of the conservative party but curiously does not 
mention suicide. Understandably, the character is bewildered after reading about his own death in the morning paper. He stops reading the newspaper, which falls from his hands as he reclines into his reading chair, watching the smoke of his cigarette spiral upwards, as he ponders his own death.

Azorín is playing with the idea that the same political system Munárriz served destroys well-meaning servants like himself. At first, for a brief time, after reading his obituary, the character feels younger and more alive than usual, but then subtle physical symptoms of illness begin to appear: "tenía algo que no podía precipitar claramente ... Sin embargo, aquello no era nada: un dolorcillo persistente en la cabeza, y unos mareos casi imperceptibles por la mañana" (47). The next morning his condition worsens, and while arranging some antique parchments, he faints. His persistent headaches and dizziness eventually lead to a nervous breakdown by the end of section four: "y don Luis, estremeciéndose nerviosamente y cabaceando después como un idiota, quedábase sumido en un marasmo embrutecedor, algo semejante a la muerte" (49). These conditions become unbearable and the well-respected politician ends his own life by shooting himself twice.

Suicide in this story clearly points to a nervous breakdown caused by years serving the Spanish government. Although the civil servant performed his tasks well, he succumbed to the political environment in which he worked. The Disaster of 1898 would come to highlight the political incompetency and general pessimism expressed in Buscapiés. This military defeat raised questions about the efficacy of the Restoration government for which the suicidal civil servant worked and underscored Spain's international decline. Spain's politicians had led the nation into a humiliating defeat, and the Restoration government, based on the constitution of 1876 with alternating power sharing, became a fantasy. It seems correct then to understand suicide in this story as a lethal consequence of an inefficient political system that was criticized by the economic class to which this character belongs. 4

Suicide not only fits within a national context of decline but it also shares in the general European pessimism expressed by authors of the fin de siécle. During this period a discussion of death seems to have been a literary prerequisite for writers. Decline, decay, sickness and exhaustion dominated the new literary content of this period. This somber esthetic, however, invited literary innovation. The concept of decadence as explained by David Weir captures this notion well. According to Weir, decadence is a historical concept that can also be understood as a literary style (I4-I6). While decadent texts reject the Realist style, they incorporate 
Realism's content. Decadent writing illustrates intensely subjective perspectives within a realist framework of social, historical as well as personal decline. Azorín's early fictions are clearly established in a realist paradigm but lack realism's objectivity. The structure of Diario de un enfermo as a diary demands a subjective perspective. Once the diarist recognizes the form of the diary as the most subjective textual genre, the form seems to unleash his imagination to explore language's more expressive qualities, while it simultaneously seems to intensify his awareness of death with the absence of his wife. The diarist observes in a particular way his urban and rural surroundings and personally struggles to put into words what he acutely feels. But these responses are all framed within a realist framework of either the cities and towns the diarist visits or the immediate social and geographical circumstances he observes.

Decadent texts are artistically self-conscious - another key feature of decadent writing (Spackman 34) - as writer-characters reflect not only on their illness or death but also on various aspects of their craft - words, structure, content, theory, and other elements of literary creation. José Martínez Ruiz channeled his own concerns about illness and writing into the creation of his characters. In the character "Azorín," this reflection is so intense that his works become theoretical musings on the creation of the novel itself and on literature in general. Decadent protagonists are attracted to professions related to their writing concerns; for example, characters who obsess about writing might become journalists in decadent texts (Santiáñez I83). In fact, decadent heroes all tend to be artists or intellectuals of some sort. A case in point, Azorín's short stories and novels portray over one hundred artists, writers, or intellectuals (Arregui Zamorano I04). Typically, the decadent protagonist is a solitary figure isolated from the modern world who manifests an ill-fated future and shattered conscience. These soul searching, moral characters have rejected middle class values and professions for their own "superior" ideals based in art, literature, music or philosophy. In the fin de siècle, these characteristics culminate in a new way that signals a transition from realism to modernismo. Within the context of suicide, as seen in Azorín's early fictions, language illustrates the paradoxes of the writer's existence. These tensions lead to frustration and contribute to the writerprotagonists' suicides in Bohemia and Diario. In these texts, decadence assumes a more extreme form but is artistically vital and active. It serves as an artistic topos and motivation that invites a subjective perspective that dominates the narrative structures produced during this time.

While, as historical critique, concepts or theories of decadence reached their height between the middle of the nineteenth century to the 
end of World War I and express various ideological premises of the author (Landgraf 4), this concept comes into view with Azorín in his criticisms of the political establishment in Spain of the r89os. Generally, decadents express opposition to industrialization, technology and progress in general brought on by modernization. They idealize the past as a way to critique the present decline they perceive. In Spain, decadence as a form of political criticism has a long tradition as well as in other parts of Europe (Balfour 65). Azorín's critiques of the I890s emerge as well later when he questions the value of progress in La voluntad. He also recognized this critical tendency in Spanish literature: "la literatura regeneradora, producida en I898 hasta años después, no es sino una prolongación, una continuación lógica, coherente, de la crítica política y social que desde muchos años antes a las guerras coloniales venía ejerciéndose" (Clásicos y modernos 903). For Azorín, regenerationalist literature, that is, literature inspired by a sense of national decline, can be polemical, ironic, reflexive and dark in nature, but it all serves as constructive criticism connecting his generation of writers to like-minded predecessors as far back as the sixteenth, seventeenth and eighteenth centuries.

Suicide is just one example of death in Azorín's works. Death by volition in his early writing shifts to a passive acceptance of death in his later pieces. In both, death is connected to a meditation and tension surrounding words and writing encountered by Azorín's protagonists. Blanchot's views of language parallel the tensions that Azorín's writerprotagonists must endure. The struggle to write becomes also the effort to survive. Thinking about words and writing increases these characters' awareness of death and result in their suicides. The civil servant and young bohemian writer also face negative social influences of family and government that also significantly contribute to their suicides. Finally, in Diario de un enfermo, the diarist's anguish regarding writing matches the pain he feels for his deceased wife in which case suicide is also a result of personal loss. Suicide for these writer-protagonists fittingly symbolizes their tensions with words, social and personal circumstances. In the examples of the wrtier-protagonists, death restores them to a preverbal state of silence where their struggle with words is finally over; death by suicide emphasizes the preference to die as a writer rather than to live happily as anything else but a writer.

\section{Millsaps College}


NOTES

I Facundo Tomás observes that the predominance of death reaches a highpoint with La voluntad during this first phase of Martínez Ruiz's novelistic production, i.e. Diario de un enfermo, La voluntad, Antonio Azorín and Confesiones de un pequeño filósofo (137).

2 As James Abbott notes, Azorín changes his views on historical and geographical determinism over time (Azorín y Francia 15-48; "Azorín and Taine's Determinism" 479). In his early novels, his characters are primarily shaped by historical, geographical and social circumstances without any contribution of intelligence, will, or agency. In later novels, particularly those of the I940s, Azorín allows for intelligence and will to shape one's personality, but to a limited degree. The struggle between the will and environment as determining factors is still prominent even in later novels such as El enfermo and El escritor.

3 Azorín's early works began to be critically reassessed in the I96os. This effort was largely focused on his political views and less on the literary aspects of these works. Recent criticism has given more emphasis to literary aspects in Azorín's short stories as early evidence of his lyricism and economy of style. See, for example, María Teresa Arregui Zamorrano and Joaquín Aguirre Bellver.

4 In the discussion regarding the reaction to the infamous defeat in 1898 when Spain lost Cuba, Puerto Rico and the Phillipines while suffering numerous casualities, a distinction is rarely made between nation and government. The war inspired a new sense of Spanish nationalism and public criticism toward the Restoration government. The defeat, as Sebastian Belfour has observed, was both a crisis of identity and legitimacy: "identity because Spaniards own self esteem was bound up with that of the nation; legitimacy because those to whom they had, willingly or unwillingly, entrusted the interests of the nation had signally failed to defend these interests" (68). Confidence in Spain's government weakened. Azorín and others of his literary tribe were both critical of the government but also inspired to find a new form of Spanish national identity.

\section{WORKS CITED}

А в в от т, јам е s. “Azorín and Taine’s Determinism" Hispania 46: 3 (1963): 476-479. —. Azorín y Francia. Madrid: Seminarios y Ediciones, 1973.

a guirre bellver, Jo aquín. Azorín, cronista de Cortes. Alicante: Instituto de

Cultura Juan Gil-Albert, 2002. 
ARREGUI ZAMORANO, MARÍA TERESA. Estructura y técnicas narrativas en el cuento literario de la generación del 98: Unamuno, Azorín y Baroja. Pamplona: U of Navarra, 1996.

B ALF OUR, SEB AST IAN. The End of the Spanish Empire, I898-1923. Oxford: Clarendon Press, I997.

B Lanchot, maurice. "Literature and the Right to Death." The Work of Fire. Trans. Charlotte Mandell. Stanford: Stanford UP, 1995. 300-344.

Du R K I m, E mile. Suicide: A Study in Sociology. Glencoe: Free Press, I95I.

ESCARTín GAUL, mon tS ERRAT, ED. Diario de un enfermo. By José Martínez Ruiz. I90I. Madrid: Cátedra, 2015.

GRANJE L, Luis. "Médicos y enfermos en las obras de Azorín." Baroja y otras figuras del 98. Madrid: Guadarrama, 1960. 316-335.

L AN D G RAF, DIE Mo. Decadence in Literature and Intellectual Debate since 1945. New York: Palgrave, 20I4.

lar ra, mariano jo sé. Artículos de costumbres. Ed. Luis F. Diaz Larios. Madrid: Espasa Calpe, I996.

marco me Renciano, F R An Cisco. Fronteras de la locura. Tres personajes de Azorín vistos por un psiquiatra. Valencia: Editorial J. Domenech, I947.

MARTín, FRAnCisco J., E D. Diario de un enfermo. By José Martínez Ruiz. I9oI. Madrid: Biblioteca Nueva, 2000.

MARTín EZ Ru I z, Jo SÉ. Obras completas. Ed. Ángel Cruz Rueda. Vol. I. Madrid: Aguilar, 1975 .

—. Castilla. Obras completas. Ed. Ángel Cruz Rueda. Vol. 2. Madrid: Aguilar, 1947.

—. Clásicos y modernos. Obras completas. Ed. Ángel Cruz Rueda. Vol. 2. Madrid: Aguilar, 1947.

-. Historia y vida. Madrid: Espasa-Calpe, 1962.

oXE Nh A N LER, NEIL. "Paradox and Negation in the Criticism of Maurice Blanchot." Symposium: A Quarterly Journal in Modern Literatures I6.I (1962): 36-44. RIO PÉREZ Y MiLÁ, SA NTIA go. “El problema de la muerte en Azorín.” Cuadernos Hispanoamericanos 113 (1959): 126-134.

SA N T Í ÑE Z, N IL. Investigaciones literarias: modernidad, historia de la literatura y modernismos. Barcelona: Editorial Crítica, 2002.

SPA A K M A N, B A R B AR A. Decadent Genealogies: The Rhetoric of Sickness from Baudelaire to D'Annunzio. Ithaca: Cornell UP, I989.

T O MÁs, FAC U D o. Las culturas periféricasy el síndrome del 98. Barcelona:

Anthropos, 2000.

WEIR, DA VID. Decadence and the Making of Modernism. Amherst: U of Massachusetts P, I995. 